\title{
COMMENT
}

\section{Feeding activity by the blenny Exallias brevis causes multifocal bleaching in corals: Comment on Zvuloni et al. (2011)}

\author{
Bruce A. Carlson* \\ Georgia Aquarium, 225 Baker Street, Atlanta, Georgia 30313, USA
}

\begin{abstract}
The shortbodied blenny Exallias brevis is an obligate corallivore. Studies on Hawaiian reefs and casual observations on other Pacific reefs reveal that $E$. brevis feeds on a wide variety of scleractinian corals, including the hydrocoral Millepora spp. This blenny produces distinctive circular feeding marks of ca. $2 \mathrm{~cm}^{2}$ on corals; the marks can persist for $50 \mathrm{~d}$ or more. E. brevis is indigenous to the Red Sea and may be responsible for the multifocal bleaching syndrome in Red Sea Millepora dichotoma described by Zvuloni et al. (2011; Mar Ecol Prog Ser 441:25-32).
\end{abstract}

KEY WORDS: Exallias brevis $\cdot$ Shortbodied blenny $\cdot$ Corallivore $\cdot$ Millepora spp. $\cdot$ Multifocal bleaching $\cdot$ Red Sea

Resale or republication not permitted without written consent of the publisher

\section{INTRODUCTION}

The shortbodied blenny Exallias brevis (Kner) is a combtooth blenny in the tribe Salariini (Hastings \& Springer 2009). Combtooth blennies are characterized by a single row of elongate incisiform teeth in each jaw that are used like brushes while grazing on rocky surfaces. The majority of these blennies feed on algae and detritus, but a few species such as Ecsenius sp. have been observed feeding on coral tissue (Randall et al. 1997, Carlson \& Awai 2008).

Hiatt \& Strasburg (1960) reported that Exallias brevis at Enewetak Atoll is an herbivore, but Hobson (1974) stated that in the Hawaiian Islands it feeds on coral polyps. Carlson (1978) and Sano et al. (1984) confirmed Hobson's conclusions that E. brevis is a corallivore. Carlson (1992) obtained quantitative data on the diet and feeding behavior of E. brevis, and these previously unpublished data form the basis of this Comment.

Zvuloni et al. (2011) described an apparently new 'multifocal bleaching' (MFB) syndrome in hydro- corals Millepora dicotoma and M. platyphyllia in shallow waters off Eilat in the Gulf of Aqaba, Red Sea. Photographs and descriptions published by Zvuloni et al. (2011, their Fig. 1c) bear a remarkable resemblance to the spots on Hawaiian corals resulting from the feeding activity of $E$. brevis.

\section{OBSERVATIONS AT THE HAWAIIAN ISLANDS}

Feeding was recorded over $63 \mathrm{~h}$ for 15 tagged male and 5 tagged female Exallias brevis on Hawaiian coral reefs at Hanauma Bay and Kahe Point on the island of Oa'hu, from October 21, 1980 through May 9, 1982 (Table 1). Feeding was exclusively on living corals, at rates of 13.9 and 28.4 bites $\mathrm{h}^{-1}$ for males and females, respectively. A total of 10 feeding marks were photographed and measured. Feeding bites on Porites lobata produced circular marks $2.04 \pm 0.42 \mathrm{~cm}^{2}$ (mean \pm SD) in area (ca. $1.6 \mathrm{~cm}$ diameter) (Fig. 1a,b). Macro-photographs revealed that superficial coenosarc tissue was removed while the polyps remained 
Table 1. Exallias brevis. Feeding bites (mean $\mathrm{h}^{-1}$ blenny ${ }^{-1}$ ) on corals at Hanauma Bay and Kahe Point, Oa'hu, Hawaii. Observations totaled $48 \mathrm{~h}$ for males $(\mathrm{n}=15)$, and $15 \mathrm{~h}$ for females $(\mathrm{n}=5)$

\begin{tabular}{|c|c|c|c|c|c|c|}
\hline \multirow{2}{*}{ Coral species } & \multicolumn{3}{|c|}{$\longrightarrow$ Males } & \multicolumn{3}{|c|}{ Females } \\
\hline & Bites (n) & Rate $\left(\mathrm{h}^{-1}\right)$ & Fraction (\%) & Bites (n) & Rate $\left(\mathrm{h}^{-1}\right)$ & Fraction (\%) \\
\hline Porites lobata & 589 & 12.27 & 88.0 & 229 & 15.27 & 53.8 \\
\hline Pocillopora meandrina & 65 & 1.35 & 9.7 & 76 & 5.06 & 17.8 \\
\hline Montipora spp. & 10 & 0.21 & 1.5 & 42 & 2.80 & 9.9 \\
\hline Leptastrea purpurea & 4 & 0.08 & 0.6 & 16 & 1.07 & 3.7 \\
\hline Cyphastrea ocellina & 1 & 0.02 & 0.1 & 0 & - & - \\
\hline Pavona varians & 0 & - & - & 63 & 4.20 & 14.8 \\
\hline Total & 669 & 13.94 & 99.9 & 426 & 28.40 & 100.0 \\
\hline
\end{tabular}

mostly intact within calyces. A total of 6 feeding marks were tracked over time and remained visible (pale or white) for as long as $50 \mathrm{~d}$ before the coral regenerated. Thus, over a $50 \mathrm{~d}$ period, a single $E$. brevis could produce white marks on $P$. lobata covering an aggregate area up to $1.57 \mathrm{~m}^{2}$ before the oldest marks disappear.

A video of Exallias brevis (www.youtube.com/ watch?v=Ymk8e_1YJGI) reveals that the mouth is wide open when feeding, and has the appearance of a small suction cup. During a feeding bite, the less flexible lower jaw with rigid teeth remains anchored in the coral, while the highly extensible upper jaw, with flexible teeth, sweeps across the surface of the coral removing coral tissue. The lower jaw creates a small crescent-shaped mark while the upper jaw produces a larger, nearly circular mark (Fig. 1a).
Males with nests defended areas of $9.0 \pm 2.7 \mathrm{~m}^{2}$ $($ mean $\pm \mathrm{SD} ; \mathrm{n}=8)$; territories of males without nests and of females averaged $20.3 \pm 12.0 \mathrm{~m}^{2}(\mathrm{n}=5)$ and $24.6 \pm 8.2 \mathrm{~m}^{2}(\mathrm{n}=6)$, respectively. Males caring for eggs fed in a smaller area, and thus feeding marks were more concentrated in those areas (Fig. 1b).

My observations of Exallias brevis on other Pacific island reefs were consistent with the corallivorous diet reported for the Hawaiian Island blennies, except that a wider variety of corals were included in the diet. One male E. brevis observed for $1 \mathrm{~h}$ near Motupore Island, Papua New Guinea, fed upon Acropora sp., Porites sp., Montipora sp., Pocillopora eydouxi, and Goniastrea sp. At Enewetak Atoll in the Marshall Islands, I observed a female E. brevis perched among the branches of fire coral Millepora sp., and after 5 min of observation, it fed on the coral (Fig. 1c,d).

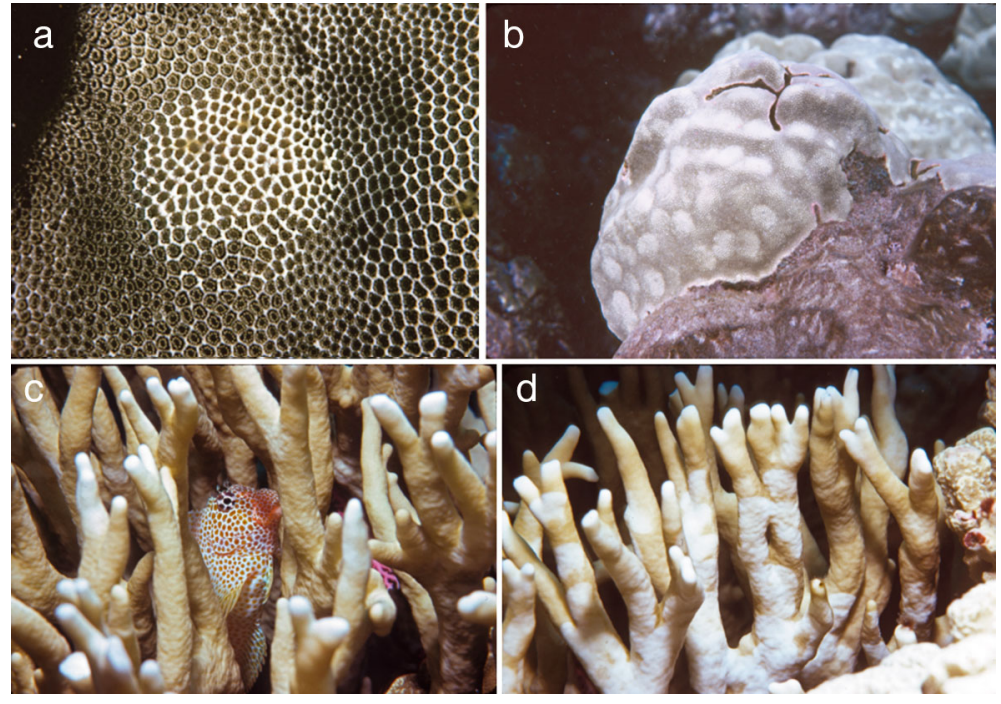

Fig. 1. Feeding marks on coral produced by Exallias brevis. (a) Single feeding mark (pale circular area) on Porites lobata, showing diagnostic pattern (Oa'hu). (b) Multiple feeding marks within a nesting male's territory (Oa'hu). (c) E. brevis in Millepora sp. colony (Enewetak). (d) Feeding marks made by blenny in (c) (Enewetak)

\section{DISCUSSION}

Exallias brevis is widespread on coral reefs throughout the Indo-Pacific region, from the Hawaiian Islands in the east to the Red Sea in the west, but it is infrequently observed due to its cryptic coloration and sedentary behavior. Biologists surveying reefs may observe E. brevis feeding marks on corals without knowing what produced them.

The marks produced by Hawaiian Exallias brevis are identical to the MFB spots illustrated by Zvuloni et al. (2011, their Fig. 1c): many of the latter spots show the diagnostic crescent on the lower edge. Furthermore, the concentrated pattern of the MFB spots is consistent with the territorial feeding and nesting activity of $E$. brevis. Zvuloni et al. (2011) considered MFB as a bleach- 
ing event, partly because they observed intact zooids within the bleached areas. However, this too is consistent with E. brevis feeding, which removes mostly coenosarc tissue and misses many of the polyps in their calices.

Randall (1983) listed Exallias brevis as indigenous to the Red Sea and noted that it is smaller in size there compared to other locations. This would explain the slightly smaller size of the MFB spots reported by Zvuloni et al., compared to the marks produced by larger E. brevis in the Hawaiian Islands. Feeding activity of this blenny appears to have gone unnoticed in the Red Sea until recently, but Christian Alter (Red Sea Environmental Centre, Dahab, Egypt) has confirmed that Red Sea E. brevis feeds on Millepora dichotoma (pers. comm.).

Zvuloni et al. (2011, p 30) correctly noted that 'pattern analysis does not usually suffice to determine the pattern-generating processes, and in the absence of microbiological data we cannot explicitly state that MFB is a syndrome caused by an infectious disease.' MFB in Red Sea Millepora dichotoma is more parsimoniously explained by the feeding activity of Exallias brevis.

Acknowledgements. I thank Stephan Moldzio, who was curious about white spots which he photographed on Millepora in the Red Sea and posted a query on the Coral-List (www.coralreef.noaa.gov) to which I responded. Gal Eyal connected Stephan's photos with MFB, and both of these

Editorial responsibility: Charles Birkeland, Honolulu, Hawaii, USA; Matthias Seaman, Oldendorf/Luhe, Germany researchers corresponded with me to resolve the issue of MFB on Millepora sp. in the Red Sea. I also thank Charles Birkeland, John E. Randall and Victor G. Springer, who reviewed the manuscript and offered editorial suggestions.

\section{LITERATURE CITED}

Carlson BA (1978) A contribution to the biology of the spotted blenny, Exallias brevis (Pisces: Blenniidae). Pac Sci 32:96

Carlson BA (1992) The life history and reproductive success of the coral blenny, Exallias brevis (Kner, 1868). PhD thesis, University of Hawaii, Honolulu, HI

Carlson BA, Awai ML (2008) Know the blennies. CoralThe Marine Aquarium Magazine, April-May 5:25-39

Hastings PA, Springer VG (2009) Systematics of the Blenniidae (combtooth blennies). In: Patzner RA, Goncalves EJ, Hastings PA, Kapoor BG (eds) The biology of blennies. Science Publishers, Enfield, p 3-30

Hiatt RW, Strasburg DW (1960) Ecological relationships of the fish fauna on coral reefs of the Marshall Islands. Ecol Monogr 30:65-127

Hobson ES (1974) Feeding relationships of teleostean fishes on coral reefs in Kona, Hawaii. Fish Bull 72:915-1031

Randall JE (1983) Red Sea fishes. IMMEL Publishing, London

Randall JE, Allen GR, Steene RC (1997) Fishes of the Great Barrier Reef and Coral Sea. University of Hawaii Press, Honolulu

Sano M, Shimizu M, Nose Y (1984) Food habits of teleostean reef fishes in Okinawa Island, Southern Japan. University Tokyo Bull 25:1-128

Zvuloni A, Armoza-Zvuloni R, Shaked Y (2011) Multifocal bleaching of Millepora dichotoma in the Gulf of Aqaba (Eilat), Red Sea. Mar Ecol Prog Ser 441:25-32

Submitted: June 15, 2012; Accepted: August 14, 2012

Proofs received from author(s): August 21, 2012 